\title{
DOES EMPLOYMENT STATUS DETERMINE COMPLETENESS OF NURSING CARE DOCUMENTATION IN MEDICAL RECORD? A PATH ANALYSIS EVIDENCE
}

\author{
Tegar Wahyu Yudha Pratama1,2), Didik Tamtomo3), \\ Endang Sutisna Sulaeman3) \\ 1)School of Health Sciences Muhammadiyah, Bojonegoro, East Java \\ ${ }^{2)}$ Masters Program in Public Health, Universitas Sebelas Maret \\ 3)Faculty of Medicine, Universitas Sebelas Maret
}

\begin{abstract}
Background: The quality of nursing care documentation is a point of challenges in nursing profession and health care industry. The mission of clinical governance is to improve the quality of nursing care documentation in the medical record. This study aimed to determine completeness of nursing care documentation in medical record.

Subjects and Method: This was a cross-sectional study carried out at Dr. Sosodoro Djatikoesmoe Hospital, Bojonegoro, East Java, in April 2018. A sample of 150 nurses was selected for this study by proportional random sampling. The dependent variable was completeness of nursing care documentation in medical record. The independent variables were tenure, responsibility, employment status, knowledge, education level, and organizational support. The data were collected by questionnaire, observation, and check list. The data were analyzed by path analysis.

Results: Completeness of nursing care documentation in medical record was directly and positively affected by tenure $(b=2.18 ; 95 \% \mathrm{CI}=1.02$ to $3.34 ; \mathrm{p}<0.001)$, responsibility $(\mathrm{b}=1.14 ; 95 \% \mathrm{CI}=0.30$ to $1.99 ; \mathrm{p}=0.008)$, employment status $(\mathrm{b}=$ $1.39 ; 95 \% \mathrm{CI}=0.54$ to $2.24 ; \mathrm{p}=0.001)$, knowledge $(\mathrm{b}=1.68 ; 95 \% \mathrm{CI}=0.34$ to 3.02 ; $\mathrm{p}=0.014)$, education $(\mathrm{b}=1.08 ; 95 \% \mathrm{CI}=0.08$ to $2.08 ; \mathrm{p}=0.034)$, and organizational support $(\mathrm{b}=1.41 ; 95 \% \mathrm{CI}=0.54$ to $2.27 ; \mathrm{p}=0.001)$. Completeness of nursing care documentation in medical record was indirectly affected by nurse education through employment status.

Conclusion: Completeness of nursing care documentation in medical record is directly affected by tenure, responsibility, employment status, knowledge, education, and organizational support.
\end{abstract}

Keywords: completeness, nursing care, documentation, tenure, responsibility

\section{Correspondence:}

Tegar Wahyu Yudha Pratama. School of Health Sciences Muhammadiyah, Bojonegoro, East Java. Email: tegar.wahyu404@gmail.com.

Mobile: +6285746085030 